\section{Evapotranspiration-based Irrigation Systems and Nitrogen Effects on Yield and Fruit Quality at Harvest in Fully Mature 'Fuji' Apple Trees over Four Years}

\author{
Esmaeil Fallahi', Bahar Fallahi, and Michael J. Kiester \\ Pomology and Viticulture Program, Parma Research and Extension Center, \\ University of Idaho, 29603 U of I Lane, Parma, ID 83660 \\ Additional index words. deficit irrigation, drip irrigation, optimum irrigation, sprinkler
}

\begin{abstract}
In a long-term study between 2008 and 2011, the use of crop evapotranspiration $(E T c)$, when a precise crop coefficient value $\left(K_{c}\right)$ was used, provided a reliable irrigation scheduling for determination of water requirement for 'Autumn Rose Fuji' apple (Malus $\times$ domestica Borkh) fully mature trees. Water use, yield, and fruit quality attributes at harvest were examined under various irrigation and nitrogen $(N)$ systems that were scheduled using ETc. Trees with a full sprinkler (FS) system received $\approx 39 \%$ to $41 \%$ more water than those with a full drip (FD) system during the period of 2008-11 growing seasons. On average, mature trees with an FS system received $5927.6 \mathrm{~L}(944 \mathrm{~mm})$, whereas those with an FD system received $3610.3 \mathrm{~L}$ of water per tree $(554.9 \mathrm{~mm})$ per growing season over the period of 2008 through 2011. Fruit from trees with FS and FD were larger, whereas those with $50 \%$ FS were smaller than those from all other treatments. Trees with $50 \%$ FS treatment received a higher volume of water but had smaller fruit size than those with $50 \%$ FD or $65 \%$ FD. Averaging values over 4 years revealed that applications of any form of deficit irrigation (DI), either by microjet irrigation or drip, increased fruit soluble solids concentration (SSC) and firmness but decreased water core at harvest. Considering yield, and quality attributes in this study, a well-calculated ETc-based FD irrigation system is recommended over any other irrigation regime. If application of deficit water is mandated, application of $65 \% \mathrm{FD}$ is preferred over $50 \%$ FS, as trees with $65 \%$ FD treatment received less water while had larger fruit than those of $50 \% \mathrm{FS}$. Trees receiving $80 \mathrm{~g} \mathrm{~N} /$ tree had lower fruit color and russet than those receiving $40 \mathrm{~g} \mathrm{~N} /$ tree. However, other yield and quality attributes were unaffected by the rate of $\mathrm{N}$ fertigation.
\end{abstract}

The decrease in irrigation water availability mandates a more efficient use of water in agriculture. Merging new orchard designs with more efficient irrigation systems can result in lower water consumption (Fallahi et al., 2007a, 2007b) while producing higher quality fruit (Behboudian and Mills, 1997; Behboudian et al., 2005; Fallahi et al., 2007a, $2007 \mathrm{~b}$; Naor, 2006). The method of irrigation and injection of nutrients, particularly nitrogen $(\mathrm{N})$ through water, affects water consumption and fruit quality in apples which are

Received for publication 9 Aug. 2017. Accepted for publication 21 Sept. 2017.

We thank the Idaho Apple Commission, International Fruit Tree Association, Washington Tree Fruit Research Commission, and the Idaho Agricultural Experiment Station for their financial support of this project. We are also thankful to the Columbia Basin and $\mathrm{C} \& \mathrm{O}$ Nurseries in Washington State for providing the experimental trees and to Richard L. Bronson, Pipeco, Fruitland, Idaho for his invaluable contribution and assistance in designing the irrigation layout and providing the irrigation materials for this project.

${ }^{1}$ Corresponding author. E-mail: efallahi@uidaho. edu.

38 through microjet sprinkler systems can improve the establishment and maintenance of orchard floor vegetation. Microjet sprinklers also create a cooler environment in the orchards under fruit-growing conditions of Washington and Idaho (E. Fallahi, personal observation). Research has been conducted with orchard fertigation through drip systems in British Columbia (Neilsen et al., 2006; Yao et al., 2001) and Europe (Zydlik and Pacholak, 2001). Although there has been some progress in understanding micro-irrigation systems and $\mathrm{N}$ application (Chun et al., 2001; Fallahi et al., 2001a, 2001b; Neilsen and Neilsen, 2006; Neilsen et al., 2004, 2008), information on yield and fruit quality in new apple cultivars under various regimes of drip or microjet sprinkler irrigation systems in the Pacific Northwest is lacking. Thus, the objective of this long-term experiment was to study the effect of five irrigation treatments consisting of two microjet sprinkler and three drip systems, using an ETc-based water scheduling, and two levels of $\mathrm{N}(40 \mathrm{~g} \mathrm{~N} /$ tree and $80 \mathrm{~g} \mathrm{~N} /$ tree $)$ on water use, yield, and harvest-time fruit quality attributes in fully mature 'Autumn Rose Fuji' trees.

\section{Materials and Methods}

Orchard establishment and general cultural practices. The experimental orchard was established at the Parma Research and Extension Center, University of Idaho, in the spring and early Summer 2002. 'Autumn Rose Fuji' trees on M.9 RN 29 (Nic 29) rootstock (Columbia Basin Nursery, Quincy, WA) were planted at $1.52 \times 4.27 \mathrm{~m}$ spacing with an east-west row orientation. 'Snow Drift' crab apple on RN 29 rootstock (C \& O Nursery, Wenatchee, WA) was planted in each row as a pollinizer between every 10 'Autumn Rose Fuji' trees. All trees were trained to a vertical axis system during the dormant season in early March each year. Tree leaders were maintained at $\approx 3.55 \mathrm{~m}$ in height. The experimental site was located at $43.7853^{\circ} \mathrm{N}$ and $116.9422^{\circ} \mathrm{W}$ and had a semiarid climate with an annual precipitation of $\approx 297 \mathrm{~mm}$ on a sandy loam soil of $\approx \mathrm{pH} 7.3$.

In general, cultural practices other than irrigation were similar to those recommended for commercial orchards in the Pacific Northwest (Washington State University, 2017). Crested wheatgrass (Agropyron cristatum (L.) Gaertn.), a drought-tolerant grass, was planted as the orchard floor cover in all treatments. Trees in all treatments were blossom thinned at $\approx 80 \%$ bloom with $5 \%$ lime sulfur, followed by one or two applications of postbloom thinners. The first postbloom thinner was a mixture of carbaryl (44.1\% by weight a.i.; Sevin XLR; 1-naphthyl N-methylcarbamate; Bayer Crop Science; Research Triangle Park, NC) and Ethephon (21.7\% a.i.; Ethrel [(2-chloroethyl) phosphonic acid]; Bayer Crop Science) at a rate of $0.125 \%$ to $0.156 \%$ of formulation and was applied at petal fall. The second postbloom thinner (when applied, depending on the crop 
load) was carbaryl (Sevin XLR) at $0.125 \%$ formulation that was applied when fruitlet diameter was $\approx 7 \mathrm{~mm}$. Fruit were subsequently hand thinned when they were $\approx 18 \mathrm{~mm}$ in diameter (around mid-June) to maintain a space of at least 12.5-15 cm between fruit. Kaolin (95\% a.i.; Surround; Englehard; Iselin, NJ) was sprayed for sunburn protection at the rate of $56.8 \mathrm{~kg} \cdot \mathrm{ha}^{-1}$ in early July, followed by three 1 -week interval applications, each at $28.4 \mathrm{~kg} \cdot \mathrm{ha}^{-1}$ every year.

The nutrients were applied to the experimental trees from 2008 through 2011. Nitrogen as UAN 32 (urea and ammonium nitrate, $32 \% \mathrm{~N}$ ) was applied at the total annual rate of either $40 \mathrm{~g} \mathrm{~N} /$ tree or $80 \mathrm{~g} \mathrm{~N} /$ tree via fertigation twice each year. The first half of each rate of $\mathrm{N}$ was applied in late May and the second one was applied at the same rate of 2 weeks after the first application each year. Potassium (when used) was applied as potassium oxide, containing $13 \% \mathrm{~K}_{2} \mathrm{O}$, via fertigation, once a year in late May. Phosphorous, as monoammonium phosphate $\left(61 \% \mathrm{P}_{2} \mathrm{O}_{5}\right)$ was applied at the rate of $150 \mathrm{~g}$ of formulation to each tree-planting hole, only once at the time of planting. Calcium and micronutrients, particularly, Fe and $\mathrm{Zn}$, were sprayed twice in spring and once in early summer each year.

Irrigation regimes. We applied five irrigation regimes on each of the five experimental rows. A row of guard trees was used between every two experimental rows. These trees received only drip irrigation to prevent any possible over-spray from the sprinkler systems in the experimental rows. Trees from the guard rows were not used for any part of the study reported here. The five irrigation regimes in this study were as follows:

1. Full sprinkler: A 30-cm microjet sprinkler (Olson Ultra-jet, Santee, CA) was connected to the lateral polyethylene line. Each microjet sprinkler was installed midway between two adjacent trees and covered a complete circle with a radius of $2.1 \mathrm{~m}$. In this treatment, the trees were irrigated once a week at the full rate of evapotranspiration (ETc) for apple starting in 2002. During the period of this study (2008-11), ETc values for fully mature trees were used. Method for ETc calculation is described in the "Calculation for water application" section.

2. Fifty percentage FS: This system was identical to the FS system (as described earlier), except that trees received only $50 \%$ of the volume that were applied to the trees with FS once a week, starting in 2002.

3. Full drip: One 16-mm drip line (Rain Bird Corporation, Azusa, CA) was installed in a $10-\mathrm{cm}$ trench (subsurface), $30 \mathrm{~cm}$ away from and parallel to the tree row on each of the north and south sides of the tree row. Each of these lines was connected to a pressure regulator to keep the water pressure constant at $1.41 \mathrm{~kg} \cdot \mathrm{cm}^{-2}$. Pressure compensating emitters were spaced at $45 \mathrm{~cm}$ on each line and each emitter delivered 2.27 $\mathrm{L} \cdot \mathrm{h}^{-1}$ of water. Pressure compensation ensured consistent flow from each inline emitter throughout the entire length of tubing and the emitter design prevented debris from clogging emitters for maximum performance. The drip line on the north side of the tree was "off-centered" with the line on the south side to have better water coverage. Trees in this system were irrigated twice a week at $100 \%$ of daily ETc (as described later), but adjusted for the ground shading area (GS). Therefore, in this treatment, liters of water applied per tree $=(E T c$ in $\mathrm{mm} /$ percent drip efficiency factor) $\times 1.52 \times 4.27 \mathrm{~m}$ spacing $\times \%$ GS. ETc and GS values for completely mature trees were used during the period of this study.

4. Sixty-five percentage FD: This system was similar to the FD system, except that the amount of water applied in this system was $65 \%$ of that applied to FD during 2008-11. This amount was applied to both sides of the trees at each application and frequency of application was the same as that of the FD system.

5. Fifty percentage FD: This system was similar to the FD system, except that the amount of water applied in this system was $50 \%$ of that applied to FD during 2008-11. This amount was applied to both sides of the trees at each application and frequency of application was the same as that of the FD system.

Calculation for water application. Irrigation started in about mid-May and ended in mid-October every year. Shortly before the first irrigation of the year, soil moisture was measured using AquaPro Sensors (Decor, $\mathrm{CA}$ ) and trees were watered to the soil saturation point. After this general irrigation, water requirements were calculated based on $\mathrm{ETc}$ where $\mathrm{ETc}=\mathrm{ETr} \times K_{\mathrm{c}}$. In this equation, ETr (Penman-Monteith reference evapotranspiration) (Allen et al., 1998) was calculated from the AgriMet Parma Weather Station data and $K_{\mathrm{c}}$ was the crop coefficient. Each year since 2002, the crop water use coefficient was calculated as $K_{\mathrm{c}}=K_{\mathrm{c}}$ base + $\% \mathrm{M} \times\left(\right.$ mature $K_{\mathrm{c}}-K_{\mathrm{c}}$ base). Percent canopy maturity $(\% \mathrm{M})$ was a measurement of canopy size and was calculated as $\% \mathrm{M}=3.05+$ $2.558 \times(\% \mathrm{GS})-0.016 \times(\% \mathrm{GS})^{2} . K_{\mathrm{c}}$ base was the base coefficient, calculated as the percent area between the rows that was occupied by a cover crop. In our experiment, spacing between rows was $4.27 \mathrm{~m}$ and the herbicide strip extended $0.61 \mathrm{~m}$ on either side of the row. Thus, $K_{\mathrm{c}}$ base was $[4.27-(0.61 \times$ $2)] / 4.27=0.71]$. Percentage of GS was estimated as the area of orchard shaded by the tree canopy at different stages of growth. Ground shading reached $62 \%$ and tree maturity reached $100 \%$ in early Aug. 2005. Thus, $K_{\mathrm{c}}$ values for mature trees were used during the course of this experiment (2008-11).
Because crested wheatgrass was planted as the orchard floor cover plant, the value for mature $K_{\mathrm{c}}$ for each month was adopted from Proebsting (1994) for apple with cover crop i.e., 0.71 in May, 0.96 in June, 1.04 in July and Aug., 1.0 in Sept., and 0.79 in Oct.

We made several random checks to test the accuracy of water delivery in various irrigation systems every year. Based on the precision in designing the irrigation systems and these random checks, we assumed the efficiency factor to be $100 \%$ for all irrigation treatments. Rainfall during the growing seasons was generally low and when it rained, this amount was subtracted from the ETc value to calculate the actual amount of irrigation needed in each application.

Yield and quality attributes. Yield per tree was recorded at harvest time. Twenty fruits were randomly sampled from each tree on Oct. 17-20 during 2008-11. For quality evaluation, fruit were weighed and fruit color was visually ranked on a scale of 1 to 5 , with $1=20 \%$ red, progressively to $5=100 \%$ red. Soluble solids concentration was measured by a temperature-compensated refractometer (Atago N1, Tokyo, Japan). Fruit firmness was measured on three peeled sides of each fruit with a Fruit Texture Analyser (Guss, Strand, Western Cape, South Africa). This texture tester measured the force needed to puncture a 7.9-mm-deep hole on each of the three peeled sides of the fruit, using an 11-mm tip. Starch degradation pattern (SDP) of equatorial slices of each fruit was recorded by comparison with the SDP standard chart developed for apples (Bartram et al., 1993).

Percentages of fruit russet, water core, and sunburn at harvest were calculated by counting the total number of fruit with each of these incidences, divided by the total number of fruit in the subsample and multiplied by 100 .

Experimental designs and statistics. The experimental design was a randomized complete block split plot with five irrigation treatments as the main effects, two levels of $\mathrm{N}$ fertilizer (nitrogen as UAN 32; 32\% nitrogen) as subplot, and five blocks (replications). Each irrigation block contained ten trees, where five of the adjacent trees randomly received $40 \mathrm{~g}$ actual $\mathrm{N} /$ tree/season whereas the other five trees received $80 \mathrm{~g}$ actual $\mathrm{N} /$ tree/ season. Data were collected during 2008 through 2011. The assumption of normal data distribution was checked by computing univariate analyses for all tree responses in this study. Analyses of variance was conducted using SAS (SAS Institute, Cary, NC), with GLM and means were compared by least significant difference at $P \leq 0.05$.

\section{Results and Discussion}

\section{Interaction}

There was no interaction between year and water treatment or between year and $\mathrm{N}$ levels for amount of applied water, tree growth, yield, or quality attributes in this study. Thus, in addition to the results for these parameters in each year, results of 
overall years from 2008 through 2011 are reported in this report.

\section{Water application}

As expected, trees used the most water in July and August in all years. On average, trees with an FS system received $\approx 39 \%$ to $41 \%$ more water than those with an FD system over the period of 2008-11 (Table 1). Averaging values over the four seasons showed that mature trees with an FS system received 5927.6 L of water per tree $(944 \mathrm{~mm})$ whereas those with an FD system received $3610.3 \mathrm{~L}$ of water per tree $(554.9 \mathrm{~mm})$ per season (Table 1). Each tree with $50 \%$ FS received more water than those of $65 \%$ FD and $50 \%$ FD systems (Table 1 ).

Trees receiving less than full levels of either sprinkler or drip irrigations had smaller tree canopies and slightly earlier leaf senescence in late October, perhaps because of increased stress in the trees with lower irrigation.

Leib et al. (2006) compared three microsprinkler irrigation systems in mature 'Fuji' trees in Washington State. In that study, the soil water content in the CI was maintained close to field capacity, which was only $60 \%$ to $70 \%$ of estimated ETc for apple without cover crop. They estimated that irrigation scheduling based on soil water measurements required $26 \%$ less water than what was predicted by the ETc model for an apple orchard without a cover crop. In that study, they applied a 3-year average of $707 \mathrm{~mm}$ of water whereas we applied an average of $944 \mathrm{~mm}$ over 4 years $(\approx 25 \%$ more $)$. This difference is perhaps largely due to the higher ETr and ETc values in Idaho than Washington. The difference could also be in part because trees receiving FS were applied with water at full ETc level in our study whereas the CI-treated trees in their experiment received water at $\approx 70 \%$ of ETc.
Rainfall in both experiments was somewhat comparable.

\section{Effects of irrigation treatments on yield and fruit quality attributes}

Fruit yield. Yield in all treatment were higher, leading to smaller fruit size when the trees were fully mature in $2008-11$ as compared with the period of 2004-07, when trees were younger (data not shown). Trees with FS and FD systems tended to have higher yield per tree than trees with other systems in 3 years $(2009,2010$, and 2011), and differences were sometimes significant (Table 2). When these trees were younger, trees with DI were more precocious and had higher yield in the early years of their production because of the induction of water stress and more spur formation (data not shown).

Because trees with an FD system received less water than those with an FS system (Table 1) and had higher yield per tree than those with $50 \% \mathrm{FS}, 65 \% \mathrm{FD}$, and $50 \% \mathrm{FD}$ (Table 2), we suggest that FD is a preferred method of irrigation over other systems for 'Fuji' apples as far as yield and water consumption factors are considered. Trees with FS and FD irrigation always had higher TCA and more new shoots and foliage (data not shown) than those with other treatments in 2008-11.

Leib et al. (2006) reported that yield of 'Fuji' apple in DI and partial zone systems were similar to those of CI in Washington State. Lack of difference in their experiment is likely because they had a shorter term study and the irrigation volume applied in their control trees was only $60 \%$ to $70 \%$ of estimated ETc.

Fruit weight. Fruit from trees with FS and FD were significantly larger than those from all other treatments (Table 2). Fruit from trees receiving 50\% FS treatment were significantly smaller than those from all other treatments during 3 of 4 years (2008, 2009, and 2010). This observation suggests that trees require irrigation at full $\mathrm{ET}_{\mathrm{C}}$ rates to produce larger fruit, and reduction of water application to $50 \% \mathrm{FS}, 65 \% \mathrm{FD}$, and $50 \% \mathrm{FD}$ will result in smaller fruit size.

Although the volume of water applied to the trees with $50 \%$ FS was more than that applied to the trees with 65\% FD and 50\% FD treatments (Table 1), fruit weight in trees with $65 \%$ FD and $50 \%$ FD were significantly heavier than those with $50 \%$ FS in 3 years (Table 2). This result indicates that if water usage is mandated and when fruit weight is not of a major component of apple production, the use of $65 \%$ FD or $50 \%$ FD is more beneficial than the use of $50 \%$ FS for maintaining trees.

In a study in the semiarid climate of Washington State, fruit size of 'Fuji' apple in the deficit and partial zone irrigation systems was similar to that of CI (Leib et al., 2006), perhaps because the irrigation volume applied in their CI trees was only $60 \%$ to $70 \%$ of estimated ETc, but ours was not. However, our results are in agreement with Naor et al. (2008) who reported that yield and fruit size decreased as the rate of irrigation was reduced in 'Golden Delicious' apple in Israel.

Fruit color. Fruit color was not consistently affected by irrigation treatment (Table 2). However, averaging values over 2008-11 period revealed that fruit from trees receiving $50 \%$ FS treatment had slightly better (more uniform red) color than those from most other irrigation treatments, perhaps because of the presence of a less dense canopy (smaller TCA) in the $50 \%$ FS-treated tree and thus better light penetration, as reported by Lancaster (1992). Mills et al. (1994) reported that DI increased skin red color in 'Braeburn' apple. In contrast, DI did not affect fruit color in 'Pink Lady' in Australia (O'Connell and Goodwin, 2007; Talluto et al., 2008). The

Table 1. Effects of different irrigation systems on total water application per season in millimeter (mm) and liter per tree (L/tree) during growing seasons of $2008-11$.

\begin{tabular}{|c|c|c|c|c|c|c|c|c|c|c|}
\hline \multirow[b]{2}{*}{ Irrigation $^{z}$} & \multicolumn{5}{|c|}{ Water applied per season (mm) } & \multicolumn{5}{|c|}{ Water applied per season (L/tree) } \\
\hline & 2008 & 2009 & 2010 & 2011 & Avg 2008-11 & 2008 & 2009 & 2010 & 2011 & Avg 2008-11 \\
\hline FS & 997.0 & 917.4 & 933.2 & 928.4 & 944.0 & $6,480.7$ & $5,679.8$ & $5,796.3$ & $5,753.8$ & $5,927.7$ \\
\hline $50 \% \mathrm{FS}$ & 530.4 & 490.5 & 491.0 & 480.1 & 498.0 & $3,446.8$ & $3,046.2$ & $3,057.9$ & $2,981.4$ & $3,133.1$ \\
\hline FD & 583.7 & 536.7 & 547.4 & 551.9 & 554.9 & $3,798.2$ & $3,490.7$ & $3,561.8$ & $3,590.5$ & $3,610.3$ \\
\hline $65 \% \mathrm{FD}$ & 393.2 & 360.7 & 366.5 & 375.4 & 374.0 & $2,556.8$ & $2,346.6$ & $2,385.5$ & $2,443.2$ & $2,433.0$ \\
\hline $50 \% \mathrm{FD}$ & 311.4 & 286.5 & 289.1 & 294.8 & 295.5 & $2,026.5$ & $1,863.7$ & $1,880.5$ & $1,918.1$ & $1,922.2$ \\
\hline
\end{tabular}

${ }^{\mathrm{z}}$ Irrigation applied to the trees: $\mathrm{FS}=$ full sprinklers (microjet, applied at $100 \% \mathrm{ETc}$ ); $50 \% \mathrm{FS}=50 \%$ of FS; FD $=$ full drip, applied at $100 \% \mathrm{ETc}$, adjusted for ground shading; $65 \% \mathrm{FD}=65 \%$ of $\mathrm{FD} ; 50 \% \mathrm{FD}=50 \%$ of $\mathrm{FD}$.

Table 2. Effects of different irrigation regimes on tree yield per tree, fruit weight, and color of 'Autumn Rose Fuji' at harvest in 2008-11.

\begin{tabular}{|c|c|c|c|c|c|c|c|c|c|c|c|c|c|c|c|}
\hline \multirow[b]{2}{*}{ Irrigation $^{\mathrm{y}}$} & \multicolumn{5}{|c|}{ Yield (kg/tree) } & \multicolumn{5}{|c|}{$\mathrm{Wt}$ (g/fruit) } & \multicolumn{5}{|c|}{ Color $(\text { Scale of } 1 \text { to } 5)^{z}$} \\
\hline & 2008 & 2009 & 2010 & 2011 & $\begin{array}{c}\text { Avg } \\
2008-11\end{array}$ & 2008 & 2009 & 2010 & 2011 & $\begin{array}{c}\text { Avg } \\
2008-11\end{array}$ & 2008 & 2009 & 2010 & 2011 & $\begin{array}{c}\text { Avg } \\
2008-11\end{array}$ \\
\hline FS & $17.2 \mathrm{ab}^{\mathrm{x}}$ & $34.0 \mathrm{a}$ & $29.5 \mathrm{a}$ & $57.4 \mathrm{ab}$ & $34.5 \mathrm{a}$ & $277.1 \mathrm{a}$ & $262.9 \mathrm{a}$ & $271.1 \mathrm{a}$ & $239.8 \mathrm{a}$ & $262.4 \mathrm{a}$ & $3.2 \mathrm{c}$ & $3.7 \mathrm{a}$ & $3.4 \mathrm{c}$ & $3.5 \mathrm{a}$ & $3.5 \mathrm{c}$ \\
\hline $50 \% \mathrm{FS}$ & $19.4 \mathrm{a}$ & $21.4 \mathrm{~d}$ & $15.0 \mathrm{~b}$ & $42.1 \mathrm{~b}$ & $23.5 \mathrm{~b}$ & $199.3 \mathrm{c}$ & $172.6 \mathrm{c}$ & $197.7 \mathrm{~d}$ & $166.3 \mathrm{~b}$ & $184.4 \mathrm{c}$ & $3.9 \mathrm{a}$ & $3.7 \mathrm{a}$ & $4.1 \mathrm{a}$ & $3.5 \mathrm{a}$ & $3.8 \mathrm{a}$ \\
\hline FD & $18.5 \mathrm{ab}$ & $29.3 \mathrm{ab}$ & $17.9 \mathrm{~b}$ & $71.8 \mathrm{a}$ & $34.4 \mathrm{a}$ & $275.9 \mathrm{a}$ & $269.0 \mathrm{a}$ & $246.7 \mathrm{~b}$ & $230.4 \mathrm{a}$ & $255.5 \mathrm{a}$ & $3.7 \mathrm{ab}$ & $3.8 \mathrm{a}$ & $3.7 \mathrm{bc}$ & $3.7 \mathrm{a}$ & $3.7 \mathrm{ab}$ \\
\hline $65 \% \mathrm{FD}$ & $12.3 \mathrm{~b}$ & $27.6 \mathrm{bc}$ & $7.1 \mathrm{c}$ & $53.8 \mathrm{ab}$ & $27.5 \mathrm{~b}$ & $243.9 \mathrm{~b}$ & $209.2 \mathrm{~b}$ & $225.4 \mathrm{c}$ & $179.2 \mathrm{~b}$ & $208.7 \mathrm{~b}$ & $3.5 \mathrm{bc}$ & $3.7 \mathrm{a}$ & $4.0 \mathrm{ab}$ & $3.0 \mathrm{~b}$ & $3.5 \mathrm{bc}$ \\
\hline $50 \% \mathrm{FD}$ & $17.8 \mathrm{ab}$ & $22.9 \mathrm{~cd}$ & $15.0 \mathrm{~b}$ & $42.9 \mathrm{~b}$ & $24.7 \mathrm{~b}$ & $232.3 \mathrm{~b}$ & $213.1 \mathrm{~b}$ & $209.1 \mathrm{c}$ & $177.0 \mathrm{~b}$ & $207.3 \mathrm{~b}$ & $3.2 \mathrm{c}$ & $3.9 \mathrm{a}$ & $3.7 \mathrm{bc}$ & $3.4 \mathrm{a}$ & $3.6 \mathrm{abc}$ \\
\hline
\end{tabular}

${ }^{\mathrm{z}}$ Fruit skin color rating: scale of 1 to 5 , with $1=20 \%$ red, progressively to $5=100 \%$ red.

${ }^{\mathrm{y}}$ Irrigation applied to the trees: FS = full sprinklers (microjet, applied at $100 \%$ ETc).; 50\% FS = 50\% of FS; FD = full drip, applied at $100 \%$ ETc, adjusted for ground shading; $65 \% \mathrm{FD}=65 \%$ of $\mathrm{FD} ; 50 \% \mathrm{FD}=50 \%$ of $\mathrm{FD}$.

${ }^{\mathrm{x}}$ Mean separation within columns by least significant difference at $5 \%$ level. Each value within each year represents the average of five blocks, each with 10 trees. 
contradictory impacts of DI on fruit color could be due to differences between methods of water delivery (drip vs. sprinkler), cultivars, prevailing temperatures at harvest for different places, and/or volume of applied water in different DI studies.

Fruit SSC. Fruit from trees with 50\% FS had significantly higher SSC in 3 of 4 years (Table 3), perhaps because of the smaller fruit size (Table 2). Averaging values over 4 years of 2008-11 showed that trees with FS and FD systems had significantly lower SSC (Table 3). Our results are in agreement with some of the previous researchers who reported that DI increased SSC, including sucrose, glucose, fructose, and sorbitol in apple fruit, perhaps because of an increase in the concentration of dry matter (Kilili et al., 1996; Mills et al., 1994; Mpelasoka et al., 2000, 2001; Naor, 2006). Leib et al. (2006) showed that SSC in fruit from trees receiving DI was higher than in fruit from trees receiving CI. A 2-year study by O'Connell and Goodwin (2007) on 'Pink Lady' in Victoria, Australia, showed that SSC tended to be higher in trees with DI than those with full irrigation in both years. In contrast, Talluto et al. (2008) reported that 'Pink Lady' fruit from deficit and full irrigation had similar SSC. Differences in the volume of water applied in DI treatments and method of calculation for water requirement (ETc vs. soil moisture content) could partially explain the contradictory results from different researchers.

$S D P$. Averaging values over 4 years revealed that fruit from trees receiving $65 \%$ FD and 50\% FD treatments had significantly higher SDP than those from other irrigation regimes (Table 3 ). Factors that lead to a greater hydrolysis of fruit starch can result in higher
SSC in apples (Kramer, 1983). However, a simple fruit dip in iodine solution (SDP) may not always be a reliable measure of the sugar concentration of fruit. For example, in our study in 2009, fruit from trees receiving $50 \%$ FS treatment had a significantly higher SSC than those from FS irrigation regime whereas fruit in both treatments had a similar level of SDP (Table 3). This could be due to conversion of simple sugar to other metabolites.

Fruit firmness. Trees receiving FS and FD treatment had lower firmness than those receiving DI ( $50 \% \mathrm{FS}, 65 \% \mathrm{FD}$, and $50 \% \mathrm{FD})$ every year and differences were often significant (Table 3). Likewise, other researchers showed that apples from nonirrigated plots were firmer than those from irrigated plots (Assaf et al., 1975; Guelfat-Reich and BenArie, 1979; Guelfat-Reich et al., 1974). Assaf et al. (1975) indicated that fruit from trees subjected to water deficiency were smaller and thus firmer than those from conventionally irrigated trees. In contrast, some previous reports indicate that low water application may reduce apple firmness, because of the advanced maturity in fruit with water stress in 'Golden Delicious' (Drake et al., 1981) and 'Braeburn' (Mills et al., 1994). Leib et al. (2006) observed that firmness of 'Fuji' apple was unaffected by DI treatments in five of six different measurements during 2001-03. Also, Talluto et al. (2008) showed that fruit firmness was unaffected by DI treatment in 'Pink Lady' apple. These observations suggest that the impact of DI on apple fruit firmness may depend on the cultivar used in the study. Thus, a side-by-side study is required to reveal the potential cultivar-DI interactions.

Fruit russet. Averaging over the period of 2008-11, fruit from trees receiving FS and FD had significantly higher russet than those with other irrigation treatments (Table 4). A possible explanation is that trees receiving less water had smaller TCA and less dense foliage, so fruit do not get as much surface injury from the leaves during breezy or windy conditions, and thus have less russet. The lower fruit russet in these treatments may also have a physiological reason and this area deserves further investigation

Water core. Trees receiving FS and FD treatments had higher percentages of water core than those receiving DI $(50 \% \mathrm{FS}, 65 \%$ $\mathrm{FD}$, and $50 \% \mathrm{FD}$ ) every year and differences were often significant (Table 4). Marlow and Loescher (1984) and Mills et al. (1994) reported that a high concentration of sorbitol would lead to the development of water core. Water core is not desirable in most apple cultivars, although it is considered a positivequality attribute in certain markets for 'Fuji' apples. The exact mechanism for the presence of higher water core incidence in treatments with higher irrigation (FS and FD) deserves further study.

Fruit sunburn. Trees with an FS system had lower sunburn incidence than those with DI treatments every year (Table 4 ). Trees from FS had larger canopies and TCA, and more foliage (data not shown) and thus protected the fruit against direct heat.

\section{Effects of nitrogen treatments on yield and fruit quality attributes}

Trees receiving $80 \mathrm{~g} \mathrm{~N} /$ tree had significantly lower fruit red color and russet than those receiving $40 \mathrm{~g} \mathrm{~N} /$ tree every year (Table 5 ). The lower fruit color in the trees receiving $80 \mathrm{~g} \mathrm{~N} /$ tree is perhaps due to to the presence of higher chlorophyll in the fruit tissue. None of the other yield or quality attributes was

Table 3. Effects of different irrigation regimes on soluble solids concentration (SSC), starch degradation pattern, and firmness of 'Autumn Rose Fuji' at harvest in $2008-11$

\begin{tabular}{|c|c|c|c|c|c|c|c|c|c|c|c|c|c|c|c|}
\hline \multirow[b]{2}{*}{ ion $^{\mathrm{y}}$} & \multicolumn{5}{|c|}{ SSC (\%Brix) } & \multicolumn{5}{|c|}{ Starch degradation pattern $(\mathrm{SDP})^{\mathrm{z}}$} & \multicolumn{5}{|c|}{ Firmness (Newton) } \\
\hline & 2008 & 2009 & 2010 & 2011 & $\begin{array}{c}\text { Avg } \\
2008-11\end{array}$ & 2008 & 2009 & 2010 & 2011 & $\begin{array}{c}\text { Avg } \\
2008-11\end{array}$ & 2008 & 2009 & 2010 & 2011 & $\begin{array}{c}\text { Avg } \\
2008-11\end{array}$ \\
\hline FS & $15.40 \mathrm{bc}^{\mathrm{x}}$ & $14.58 \mathrm{~d}$ & $15.52 \mathrm{~b}$ & $13.85 \mathrm{~b}$ & $14.83 \mathrm{~d}$ & $3.31 \mathrm{a}$ & $3.64 \mathrm{~b}$ & $3.15 \mathrm{bc}$ & $3.48 \mathrm{c}$ & $3.39 \mathrm{c}$ & $81.2 \mathrm{~b}$ & $73.5 \mathrm{~d}$ & $79.1 \mathrm{c}$ & $80.4 \mathrm{c}$ & $78.6 \mathrm{~d}$ \\
\hline FD & $15.06 \mathrm{c}$ & $14.85 \mathrm{~d}$ & $15.88 \mathrm{~b}$ & $14.31 \mathrm{~b}$ & $15.04 \mathrm{~d}$ & $3.59 \mathrm{a}$ & $3.66 \mathrm{~b}$ & $3.52 \mathrm{ab}$ & $3.76 \mathrm{bc}$ & $3.64 \mathrm{~b}$ & $81.5 \mathrm{~b}$ & $74.4 \mathrm{~cd}$ & $83.9 \mathrm{~b}$ & $83.2 \mathrm{bc}$ & $80.8 \mathrm{c}$ \\
\hline $65 \% \mathrm{FD}$ & $15.81 \mathrm{~b}$ & $15.36 \mathrm{c}$ & $16.60 \mathrm{a}$ & $14.28 \mathrm{~b}$ & $15.43 \mathrm{c}$ & $3.26 \mathrm{a}$ & $4.58 \mathrm{a}$ & $3.04 \mathrm{c}$ & $4.73 \mathrm{a}$ & $4.04 \mathrm{a}$ & $83.7 \mathrm{ab}$ & $75.9 \mathrm{bc}$ & $90.5 \mathrm{a}$ & $85.2 \mathrm{~b}$ & $83.9 \mathrm{~b}$ \\
\hline $50 \% \mathrm{FD}$ & $15.58 \mathrm{~b}$ & $15.98 \mathrm{~b}$ & $15.98 \mathrm{~b}$ & $15.20 \mathrm{a}$ & $15.70 \mathrm{~b}$ & $3.73 \mathrm{a}$ & $4.41 \mathrm{a}$ & $3.52 \mathrm{ab}$ & $4.03 \mathrm{~b}$ & $3.94 \mathrm{a}$ & $83.7 \mathrm{ab}$ & $77.5 \mathrm{~b}$ & $88.8 \mathrm{a}$ & $90.9 \mathrm{a}$ & $85.2 \mathrm{~b}$ \\
\hline
\end{tabular}

${ }^{\mathrm{z}}$ Fruit SDP: 1 = lowest, progressively to $6=$ highest, using the chart of Bartram et al. (1993).

${ }^{\mathrm{y}}$ Irrigation applied to the trees: $\mathrm{FS}=$ full sprinklers (microjet, applied at $100 \% \mathrm{ETc}$ ); $50 \% \mathrm{FS}=50 \%$ of FS; FD $=$ full drip, applied at $100 \% \mathrm{ETc}$, adjusted for ground shading; $65 \% \mathrm{FD}=65 \%$ of $\mathrm{FD} ; 50 \% \mathrm{FD}=50 \%$ of $\mathrm{FD}$.

${ }^{\mathrm{x}}$ Mean separation within columns by least significant difference at $5 \%$ level. Each value within each year represents the average of five blocks, each with 10 trees.

Table 4. Effects of different irrigation regimes on fruit russet, water core, and sunburn in 'Autumn Rose Fuji' at harvest in 2008-11.

\begin{tabular}{|c|c|c|c|c|c|c|c|c|c|c|c|c|c|c|c|}
\hline \multirow[b]{2}{*}{ Irrigation $^{2}$} & \multicolumn{5}{|c|}{ Russet $(\%)^{y}$} & \multicolumn{5}{|c|}{ Water core $(\%)^{y}$} & \multicolumn{5}{|c|}{ Sunburn $(\%)^{y}$} \\
\hline & 2008 & 2009 & 2010 & 2011 & $\begin{array}{c}\text { Avg } \\
2008-11\end{array}$ & 2008 & 2009 & 2010 & 2011 & $\begin{array}{c}\text { Avg. } \\
2008-11\end{array}$ & 2008 & 2009 & 2010 & 2011 & $\begin{array}{c}\text { Avg } \\
2008-11\end{array}$ \\
\hline FS & $11 \mathrm{a}^{\mathrm{x}}$ & $44 \mathrm{a}$ & $18 \mathrm{a}$ & $26 \mathrm{bc}$ & $25 \mathrm{a}$ & $74 \mathrm{ab}$ & $75 \mathrm{ab}$ & $64 \mathrm{ab}$ & $63 \mathrm{a}$ & $68 \mathrm{a}$ & $9.8 \mathrm{~b}$ & $12.6 \mathrm{~b}$ & $8.9 \mathrm{c}$ & $11.8 \mathrm{a}$ & $10.9 \mathrm{~b}$ \\
\hline $65 \% \mathrm{FD}$ & $12 \mathrm{a}$ & $22 \mathrm{~cd}$ & $17 \mathrm{ab}$ & $19 \mathrm{c}$ & $18 \mathrm{~b}$ & $68 \mathrm{ab}$ & $62 \mathrm{bc}$ & $43 \mathrm{c}$ & $22 \mathrm{~b}$ & $45 \mathrm{~b}$ & $12.2 \mathrm{ab}$ & $16.9 \mathrm{ab}$ & $17.5 \mathrm{ab}$ & $18.3 \mathrm{a}$ & $17.3 \mathrm{a}$ \\
\hline $50 \% \mathrm{FD}$ & $10 \mathrm{a}$ & $28 \mathrm{bc}$ & $10 \mathrm{~b}$ & $29 \mathrm{~b}$ & $19 \mathrm{~b}$ & $61 \mathrm{~b}$ & $60 \mathrm{bc}$ & $46 \mathrm{bc}$ & $27 \mathrm{~b}$ & $49 \mathrm{~b}$ & $17.2 \mathrm{ab}$ & $21.6 \mathrm{a}$ & $16.0 \mathrm{abc}$ & $16.1 \mathrm{a}$ & $17.7 \mathrm{a}$ \\
\hline
\end{tabular}

${ }^{\mathrm{Z}}$ Irrigation applied to the trees: $\mathrm{FS}=$ full sprinklers (microjet, applied at $100 \% \mathrm{ETc}$ ); $50 \% \mathrm{FS}=50 \%$ of FS; FD $=$ full drip, applied at $100 \% \mathrm{ETc}$, adjusted for ground shading; $65 \% \mathrm{FD}=65 \%$ of $\mathrm{FD} ; 50 \% \mathrm{FD}=50 \%$ of $\mathrm{FD}$.

${ }^{\mathrm{y}}$ Percentage of each incidence was calculated as the number of affected fruit divided by the total number in the subsample and multiplying by 100.

${ }^{\mathrm{x}}$ Mean separation within columns by least significant difference at $5 \%$ level. Each value within each year represents the average of five blocks, each with 10 trees. 
significantly affected by the rate of $\mathrm{N}$ application (Table 5).

\section{Conclusion}

A significantly greater volume of water is required for trees under full microjet sprinkler systems than those with drip systems. However, application of water through a drip system, calculated based on full ETc rate and adjusted for groundcover, can result in major water saving and often improve yield and fruit quality attributes. Application of 50\% FS reduces yield and fruit weight whereas it may improve fruit color, SSC, and firmness. Fruit sunburn is reduced with application of water at full ETc rate in both sprinkler (FS) and drip (FD) systems because trees under these irrigation systems have a larger canopy and more foliage. Considering growth, yield, and fruit quality attributes in this study, a well-calculated ETc-based FD irrigation system is recommended over any other irrigation regime for modern high-density apple orchards. 'Fuji' apple trees can be maintained with drip irrigation at $65 \%$ of drip ETc rate (i.e., $65 \% \mathrm{FD}$ ) if certain fruit quality attributes, such as fruit weight, are not of major concern for production. Application of water through a drip system at $65 \%$ of FD ETc rate would be preferred over the $50 \%$ FD regime if better fruit size at a reduced irrigation level was desired.

With an increasing demand for new cultivars, higher orchard tree density, and different canopy architectures, the impact of various irrigation systems and rates of water application on fruit quality and yield of apples needs to be further studied. Also, a concerted effort by various researchers is required to conduct an extensive study with a uniform set of cultivars and uniform protocol of irrigation over a wide range of climates to reveal the potential interactions between DI and apple yield and quality.

\section{Literature Cited}

Allen, R.G., L.S. Pereira, D. Raes, and M. Smith. 1998. Crop evapotranspiration. Guidelines for computing crop water requirements. FAO Irrig. Drain. Pap. 56. FAO, Rome, Italy.

Assaf, R., I. Levin, and B. Bravdo. 1975. Effect of irrigation regimes on trunk and fruit growth rates, quality and yield. J. Hort. Sci. 50:481-493.

Bartram, R.D., W. Bramlage, E.M. Kupferman, K.L. Olsen, M.E. Patterson, and J. Thompson. 1993. Apple maturity program handbook. USDA-ARS Tree Fruit Research Station, Wenatchee, WA.

Behboudian, M.H. and T.M. Mills. 1997. Deficit irrigation in deciduous orchards. Hort. Rev. 21:105-131

Behboudian, M.H., B.S. Mpelasoka, Z. Singh, and T.M. Mills. 2005. Quality responses of deciduous fruits to deficit irrigation, p. 33-43. In: R. Dris (ed.). Fruits: Growth, nutrition, and quality. WFL Publisher (Science \& Technology), Helsinki, Finland.

Chun, I.J., E. Fallahi, W.M. Colt, B. Shafii, and R.R. Tripepi. 2001. Effects of rootstocks and microsprinkler fertigation on mineral concentrations, yield, and fruit color of 'BC-2 Fuji' apple. J. Amer. Pomol. Soc. 55:197-205.
Drake, S.R., E.L. Proebsting, M.O. Mahan, and J.B. Thompson. 1981. Influence of trickle and sprinkle irrigation on 'Golden Delicious' apple quality. J. Amer. Soc. Hort. Sci. 106:255-258.

Fallahi, E., I.J. Chun, G.H. Neilsen, and W.M. Colt. $2001 \mathrm{~b}$. Effects of three rootstocks on photosynthesis, leaf mineral nutrition, and vegetative growth of 'BC-2 Fuji' apple trees. J. Plant Nutr. 24:827-834.

Fallahi, E., W.M. Colt, and B. Fallahi. 2001a. Optimum ranges of leaf nitrogen for yield, fruit quality, and photosynthesis in 'BC-2 Fuji'. Apple. J. Amer. Pomol. Soc. 55:68-75.

Fallahi, E., B. Fallahi, B. Shafii, and B. Morales. 2007a. Water use, tree growth, and leaf mineral nutrients of young 'Fuji' apples as influenced by different irrigation systems. Acta Hort. 721:63-70.

Fallahi, E., R. Ratnaprabha, R. Tripepi, B. Shafii, and B. Fallahi. 2007b. Tree growth, yield, fruit quality, and mineral partitioning as affected by rootstock and irrigation methods. Intl. J. Fruit Sci. 7:3-24.

Guelfat-Reich, S., R. Assaf, B.A. Bravdo, and I. Levin. 1974. The keeping quality of apples in storage as affected by different irrigation regimes. J. Hort. Sci. 49:217-225.

Guelfat-Reich, S. and R. Ben-Arie. 1979. Effect of irrigation on fruit quality at harvest and during storage. Proc. XV Intl. Congr. Refrig., Belgium 3:423-427.

Kilili, A.W., M.H. Behboudian, and T.M. Mills. 1996. Composition and quality of 'Braeburn' apples under reduced irrigation. Scientia Hort. 67:1-11.

Kramer, P.J. 1983. Water relations of plants. Academic Press, New York, NY.

Lancaster, J.E. 1992. Regulation of skin color in apples. Crit. Rev. Plant Sci. 10:487-502.

Leib, B.G., H.W. Caspari, C.A. Redulla, P.K. Andrews, and J.J. Jabro. 2006. Partial root zone drying and deficit irrigation of 'Fuji' apples in a semi-arid climate. Irr. Sci. 24:85-99.

Marlow, G.C. and W.H. Loescher. 1984. Water core. Hort. Rev. 6:189-251.

Mills, T.M., M.H. Behboudian, P.Y. Tan, and B.E Clothier. 1994. Plant water status and fruit quality in 'Braeburn' apples. HortScience 29: 1274-1278.

Mpelasoka, B.S., M.H. Behboudian, J. Dixon, S.M. Neal, and H.W. Caspari. 2000. Improvement of fruit quality and storage potential of 'Braeburn' apple through deficit irrigation. J. Hort. Sci. Biotechnol. 75:615-621.

Mpelasoka, B.S., M.H. Behboudian, and S. Ganesh. 2001. Fruit quality attributes and their interrelationships of 'Braeburn' apple in response to deficit irrigation and to crop load. Gartenbauwissenschaft 66:247-253.

Naor, A. 2006. Irrigation scheduling and evaluation of tree water status in deciduous orchards. Hort. Rev. 32:111-165.

Naor, A., S. Naschitz, M. Peres, and Y. Gal. 2008. Responses of apple fruit size to tree water status and crop load. Tree Physiol. 28:1255-1261.

Neilsen, D., G.H. Neilsen, D. Gregory, T. Forge, and B.J. Zebarth. 2008. Drainage losses of water, $\mathrm{N}$ and $\mathrm{P}$ from micro-irrigation systems in a young, high density apple planting. Acta Hort. 792:483-490.

Neilsen, D., S. Smith, G. Frank, W. Koch, Y. Alila, W. Merritt, B. Taylor, M. Barton, J. Hall, and S. Cohen. 2006. Potential impacts of climate change on water availability for crops in the Okanagan Basin, British Columbia. Can. J. Soil Sci. 86:909-924.

Neilsen, G.H. and D. Neilsen. 2006. Response of high density apple orchards on course-textured 
soil to form of potassium applied by fertigation. Can. J. Soil Sci. 86:749-755.

Neilsen, G.H., D. Neilsen, and L.C. Herbert. 2009. Nitrogen fertigation concentration and timing of application affect nitrogen nutrition, yield, firmness, and color of apples grown at high density. HortScience 44:1425-1431.

Neilsen, G.H., D. Neilsen, L.C. Herbert, and E.J. Hogue. 2004. Response of apple to fertigation of $\mathrm{N}$ and $\mathrm{K}$ under conditions susceptible to the development of K deficiency. J. Amer. Soc. Hort. Sci. 129:26-31.

Neilsen, G.H., P. Parchomchuck, and D. Neilsen. 1994. Fertigation of fruit trees: The B.C. experience, p. 191-199. In: A.B. Peterson and
R.G. Stevens (eds.). Tree fruit nutrition. Good Fruit Grower, Yakima, WA.

O'Connell, M.G. and I. Goodwin. 2007. Responses of 'Pink Lady' apple to deficit irrigation and partial root zone drying: Physiology, growth, yield, and fruit quality. Austral. J. Agr. Res. 58:1068-1076.

Proebsting, E. 1994. Strategy development for managing drought, p. 39-50. In: K.M. Williams and T.W. Ley (eds.). Tree fruit irrigation. Good Fruit Grower, Yakima, WA.

Talluto, G., V. Farina, G. Volpe, and R. Lo Bianco. 2008. Effects of partial root zone drying and rootstock vigor on growth and fruit quality of 'Pink Lady' apple trees in Mediter- ranean environments. Austral. J. Agr. Res. 59: 785-794.

Washington State University. 2017. Washington State University Tree Fruit Research and Extension Center. 10 Aug. 2017. <http://www. tfrec.wsu.edu>.

Yao, S., G.H. Neilsen, and D. Neilsen. 2001. Effects of water stress on growth and mineral composition of 'Gala' apple fruit. Acta Hort. 564:449-456.

Zydlik, Z. and E. Pacholak. 2001. Fertigation effects on the concentration of mineral components in the soil and leaves, and the yield and quality of fruits in two apple tree cultivars. Acta Hort. 564:457-463. 